\title{
Pelatihan Memelihara Alat Jahit (Maintenance \& Repair) Kelurahan Malasom Kabupaten Sorong
}

\author{
Retno Dewi Wijiastuti ${ }^{1}$, Evi Mufrihah Zain ${ }^{2}$, Evi Ardita Sari ${ }^{3}$ \\ 1, 2, 3 Fakultas Ekonomi, Universitas Muhammadiyah Sorong, Indonesia \\ Email: d3wieno@gmail.com
}

\begin{abstract}
ABSTRAK
Tujuan penelitian yang ingin dicapai secara spesifik adalah untuk memperoleh data tentang manfaat hasil belajar keterampilan menjahit tailor ditinjau dari keterampilan menyiapkan dan memperbaiki mesinjahit. Penelitian ini dilakukan di Kelurahan Malasom Kabupaten Sorong. Teknik Analisis data hanya sampai pada taraf deskripsi Kualitatif. Data dikumpulkan melalui wawancara dan observasi. Hasil pelaksanaan pelatihan memelihara alat jahit ini, warga masyarakat yang datang dan menjadi peserta memperlihatkan antusiasmenya dalam merawat alat jahit agar awet dan tidak ada kendala dalam menggunakan alat jahit. Pelatihan memelihara alat jahit ini, mendapatkan respon yang luar biasa dari peserta pelatihan bahkan mereka meminta agar pemateri bisa melakukan pelatihannya secara berkesinambungan di Kelurahan Malasom di masing-masing RT yang ada dalam lingkup Kelurahan Malasom Kabupaten Sorong. Manfaat dari memelihara alat jahit dengan benar perlu di dukung oleh pengetahuan ilmiah yang relevan sehinga meningkatkan serta memperkuat kesadaran masyarakat akan pentingnya merawat mesin dan alat jahit agar dapat bertahan lama dan awet untuk digunakan dalam waktu yang lama.
\end{abstract}

Kata Kunci: Maintenance dan Repair, Kelurahan Malasom, Kabupaten Sorong.

\section{Sewing Equipment Maintenance Training (Maintenance \& Repair) Malasom Village, Sorong Regency}

\begin{abstract}
ABSTRAK
The research objective to be specifically achieved is to obtain data on the benefits of learning outcomes of tailor sewing skills in terms of the skills to prepare and repair sewing machines. This research was conducted in Malasom Village, Sorong Regency. The data analysis technique is only up to the qualitative description level. Data were collected through interviews and observations. The results of the training to maintain this sewing tool, community members who came and became participants showed their enthusiasm in caring for sewing tools so that they were durable and there were no obstacles in using sewing tools. The training to maintain this sewing tool received an extraordinary response from the training participants and they even asked the presenters to carry out the training on an ongoing basis in the Malasom Village in each RT within the scope of the Malasom Village, Sorong Regency. The benefits of maintaining sewing tools properly need to be supported by relevant scientific knowledge so as to increase and strengthen public awareness of the importance of caring for sewing machines and tools so that they can last a long time and be used for a long time.
\end{abstract}

Keywords: Maintenance and Repair, Malasom Village, Sorong Regency.

\section{PENDAHULUAN}

Pelatihan adalah proses pembelajaran yang dilaksanakan untuk mencapai suatu kompetensi tertentu dimana materi, metode dan fasilitas pelatihan serta lingkungan belajar yang ada terfokus kepada pencapaian unjuk kerja pada kompetensi yang dipelajari. Menurut Mangkunegara (2009: 
50) pelatihan adalah suatu proses pendidikan jangka pendek yang mempergunakan prosedur sistematis dan teroganisasi untuk meningkatkan pengetahuan dan ketrampilan dalam pelaksanaan tugas tertentu. (Wahyuningtyas, 2013)

Menurut UU Ketenagakerjaan No. 13 Tahun 2003 di jelaskan bahwa Pelatihan kerja diselenggarakan dan di arahkan untuk membekali, meningkatkan, dan mengembangkan kompetensi kerja guna meningkatkan kemampuan, produktivitas, dan kesejahteraan. Pelatihan kerja dilaksanakan dengan memperhatikan kebutuhan pasar kerja dan dunia usaha, baik di dalam maupun di luar hubungan kerja. (Kusnadi, 2020)

Kompetensi adalah kemampuan kerja setiap individu yang mencakup aspek pengetahuan, keterampilan, dan sikap kerja yang sesuai dengan standar yang ditetapkan (Peraturan Dirjen PLP, 2006). Menurut Lefrancois dalam Bafadal,I. (2000) kompetensi merupakan kapasitas untuk melakukan sesuatu, yang dihasilkan dari proses belajar.(Ni Wayan Marti, 2017)

Keterampilan menurut Sheldon Shaeffer (dalam Departemen Pendidikan Nasional, 2007, hlm.7) bahwa "keterampilan merupakan bekal bagi tenaga kerja untuk mandiri secara ekonomi dan sosial, dan dapat memberi masa depan yang lebih baik untuk memasuki arus utama masyarakat". (Latifa \& Maeliah, 2016)

Kinerja yang memadai membutuhkan komitmen yang kuat dan bermakna jika didukung oleh unsur pengetahuan, keterampilan dan sikap. Dari ketiga unsur tersebut dapat dioptimalkan melalui pelatihan, pendidikan dan pengembangan dimana menurut Mangkuprawija (2000) dalam bukunya manajemen sumber daya manusia strategi memberikan batasan sebagai berikut : Pendidikan adalah kegiatan alih ilmu (transfer of knowledge) tentang subyek tertentu, bersifat universal, terstruktur dan bermanfaat untuk kepentingan jangka panjang. Dengan demikian pengembangan intelektual sumber daya manusia perlu mendapat perhatian secara efektif dan efisien. (Http://Www.Mb.Ipb.Ac.Id, n.d.).

Di Kelurahan Malasom Kabupaten Sorong, diselenggarakan pelatihan berbasis kompetensi yang merujuk pada pemeliharaan dan perbaikan alat jahit (Maintenance \& Repair). Pada kompetensi ini peserta akan dibimbing pengetahuan, keterampilan dan sikap kerja yang diperlukan untuk memelihara alat jahit di lingkungan busana. Pemeliharaan (maintenance) merupakan suatu tindakan memelihara mesin dan komponen atau perbaikan agar tercipta proses produksi yang efektif. Faktor utama produksi adalah pemeliharaan, sehingga pemeliharaan akan terus dilakukan secara berkala agar mesin tidak mengalami kerusakan yang lebih parah. (Pasuruan, n.d.).

Menurut Assauri (2008:134), pemeliharaan (maintenance) adalah kegiatan untuk memelihara atau menjaga fasilitas atau peralatan pabrik dan mengadakan perbaikan, penyesuaian, dan 
penggantian yang diperlukan agar terdapat suatu keadaan operasi produksi yang memuaskan sesuai dengan apa yang telah direncanakan, maka fasilitas dapat digunakan untuk proses produksi atau sebelum jangka waktu yang direncanakan tercapai. Sedangkan menurut Tampubolon (2004:247), pemeliharaan (maintenance) merupakan semua aktivitas, termasuk menjaga sistem peralatan dan mesin supaya selalu dapat melaksanakan pesanan pekerjaan. (Mentari, Dini, 2017)

Sehingga diharapkan dengan adanya pelatihan di Kelurahan Malasom Kabupaten Sorong ini, dapat membantu masyarakat agar dapat mengembangkan pengetahuan, keterampilan dan sikap agar siap untuk kerja pada lingkungan kerja sesuai kompetensinya. Jika seseorang kompeten dalam pekerjaan maka ia telah memiliki keterampilan, pengetahuan dan sikap yang perlu ditampilkan secara efektif ditempat kerja, sesuai dengan standar yang telah disetujui.

\section{METODE PENELITIAN}

\section{Waktu, Tempat dan Peserta}

Kegiatan Pelatihan di laksanakan di Kelurahan Malasom Kabupaten Sorong. Adapun peserta pelatihan terdiri dari ibu-ibu rumah tangga, anggota PKK Kelurahan Malasom dan juga bapakbapak yang tidak ketinggalan turut ambil bagian dalam pelatihan.

\section{Bahan dan Alat Pelatiha}

Adapun bahan dan alat yang digunakan dalam pelatihan memelihara alat jahit yakni mesin jahit, Benang, jarum, setikan, lap flannel, lap katun dan blacu, sikat kecil atau kuas.

\section{Tahapan pelatihan}

Sebelum memulai demontrasi cara memelihara alat jahit, terebih dahulu pemateri memaparkan pengenalan tentang mesin jahit dan perawatannya, maksud dan tujuannnya, keuntungan dari memelihara alat jahit, alasan kenapa alat jahit harus ada perawatan.

Setelah proses pemaparan selesai, pemateri memulai sesi diskusi dengan warga masyarakat atau peserta pelatihan yang hadir. Hal ini dilakukan agar para peserta bisa memahami dengan jelas tentang memelihara alat jahit.

Adapun tahapan cara pemeliharaan mesin jahit : 1) Bersihkan bagian luar mesin dari debu-debu dan sisa-sisa benang dan kain dengan lap halus; 2) Bersihkan bagian dalam mesin dengan cara melepas seperti halnya sekoci; 3) Kencangkan baut atau sekrup yang longgar dengan obeng; 4) Meminyaki mesin; 5) Setelah mesin diminyaki, dibiarkan beberapa saat, kemudian lap-lap sisasisa minyak yang ada pada bagian mesin dengan kain halus; 6) Tutup mesin yang telah dibersihkan jika tidak dipergunakan. 


\section{HASIL DAN PEMBAHASAN}

Secara umum penelitian ini bertujuan untuk memperoleh data tentang manfaat hasil belajarketerampilan menjahit sebagai kesiapan peserta pelatihan untuk magang dan kerja. Tujuan penelitianyang ingin dicapai secara spesifik adalah untuk memperoleh data tentang manfaat hasil belajarketerampilan menjahit tailor ditinjau dari keterampilan menyiapkan dan memperbaiki mesin jahit. Dalam pelaksanaan pelatihan memelihara alat jahit ini, warga masyarakat yang datang dan menjadi peserta memperlihatkan antusiasmenya dalam merawat alat jahit agar awet dan tidak ada kendala dalam menggunakan alat jahit.

\section{Pemeliharaan Mesin Jahit}

Pengetahuan pemeliharaan mesin jahit berkaitan dengan membersihkan mesin jahit, dan memberi pelumas atau minyak pada mesin jahit. Keterampilan memperbaiki kerusakan mesin berkaitan dengan kerusakan kecil pada mesin ketika menjahit seperti benang atas putus-putus, benang bawah putus-putus, jarum patah, setikan tidak teratur, benang bawah menggumpal, bahan tidak bergerak dan bunyi mesin yang keras.

Keterampilan mempersiapkan kelengkapan mesin jahit yaitu berkaitan dengan jenis dan nomor jarum mesin jahit yang digunakan, jarak setikan per inchi, pengaturan tegangan benang, dan pemasangan rumah kumparan pada mesin. Pengetahuan tersebut merupakan salah satu keterampilan yang harus dimiliki oleh peserta pelatihan untuk dapat menjadi operator jahit di tailor. Dalam keadaan tidak terpakai mesin jahit harus selalu ditutup, supaya debu tidak masuk ke bagiandalam mesin jahit. Untuk membersihkan mesin jahit kita memerlukan :

\section{Lap flannel}

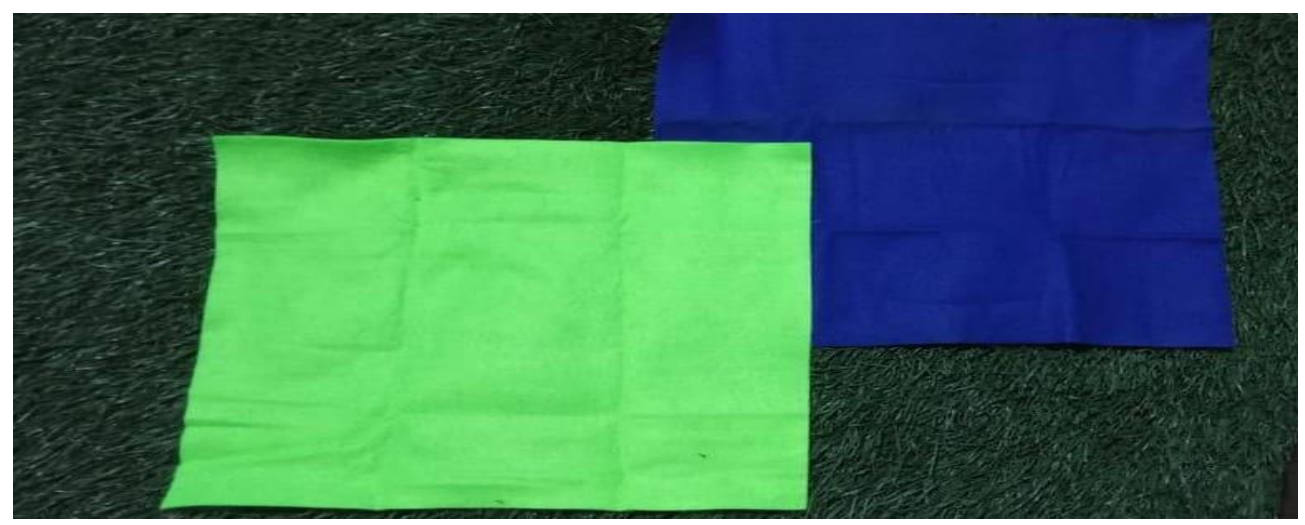

Gambar 1. Lap flannel. 


\section{Lap katun dan blacu}

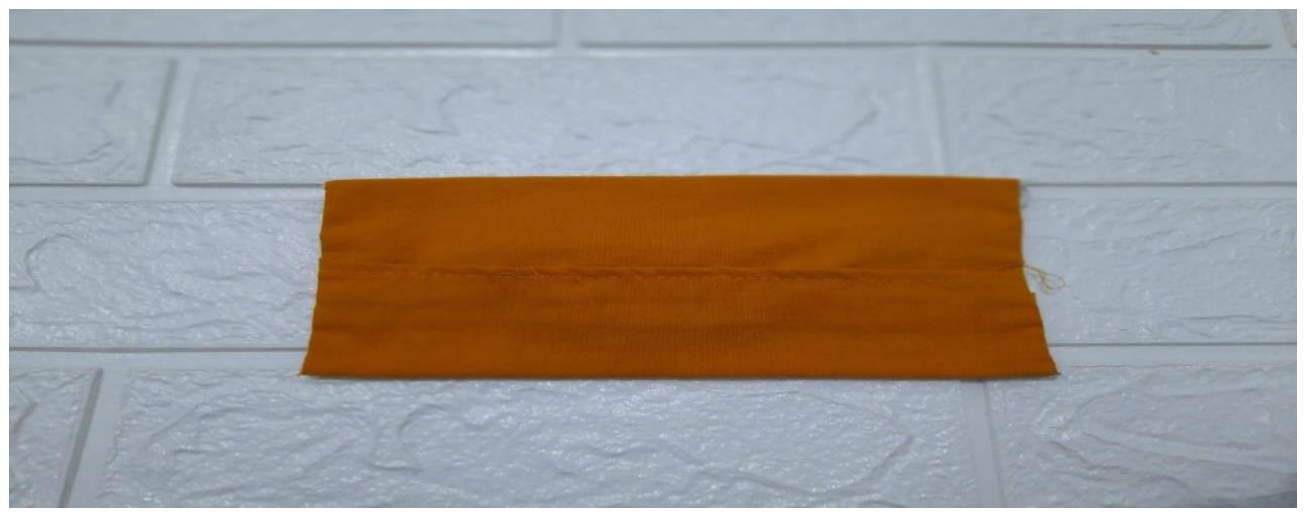

Gambar 2. Lap katun.

\section{Sikat kecil atau kuas}
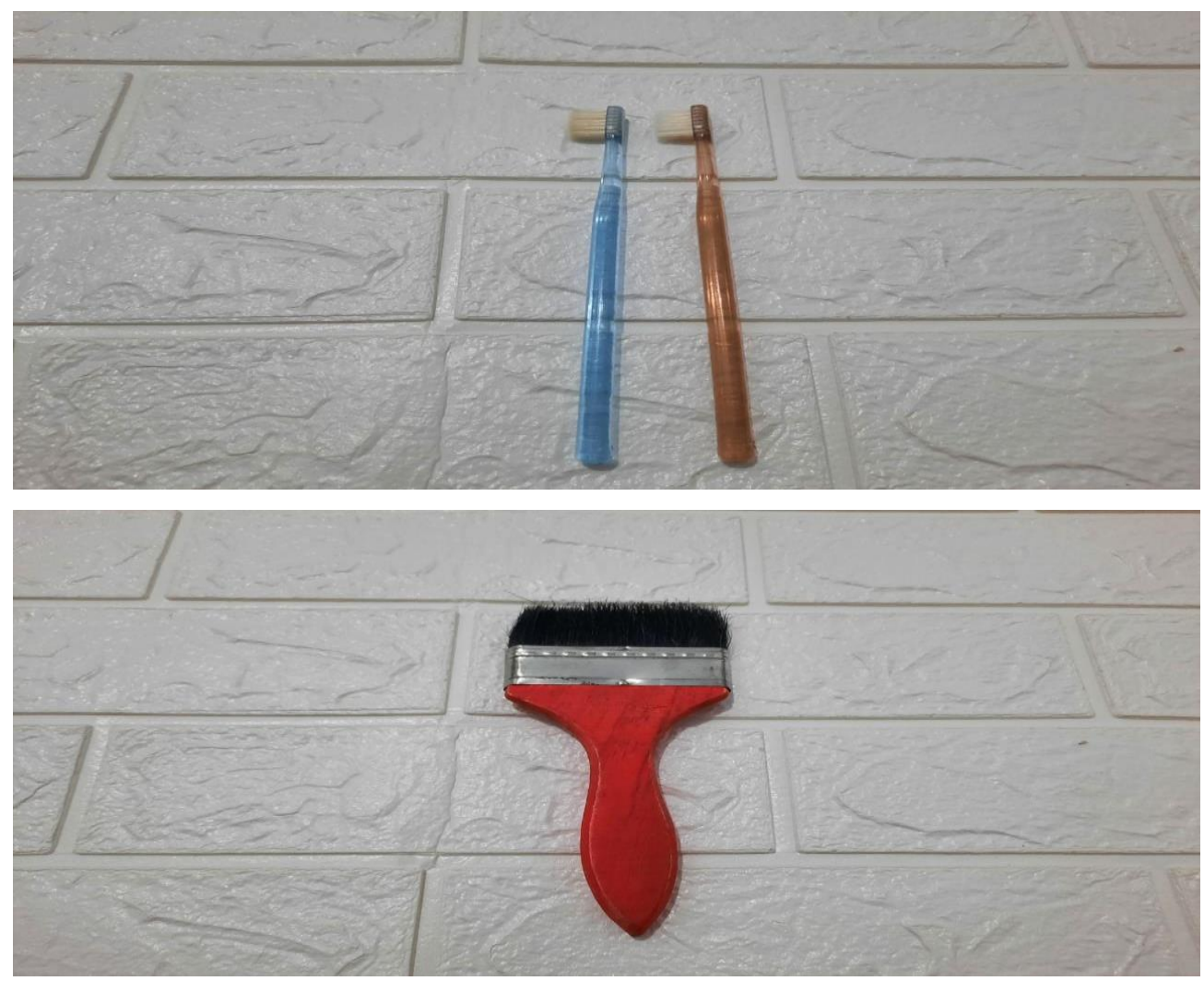

Gambar 3. Sikat dan kuas.

Minyak mesin atau bila tidak ada dapat diganti dengan campuran minyak kelapa dan minyak tanah dengan perbandingan 1:1. 
Cara pemeliharaan mesin jahit : 1) Bersihkan bagian luar mesin dari debu-debu dan sisa-sisa benang dan kain dengan lap halus; 2) Bersihkan bagian dalam mesin dengan cara melepas seperti halnya sekoci atau dengan cara membalikannya. Membersihkan debu-debu dan kotoran yang menempel dengan kuas asehingga debu-debu yang menempel bersih. Bersihkan/lap mesin dengan kain halus bagian bodinya setiap akan dan setelah selesai digunakan. Untuk menjaga kebersihan mesin sebaiknya jika tidak dipergunakan mesin ditutup; 3) Kencangkan baut atau sekrup yang longgar dengan obeng, setiap kali mesin akan dipergunakan dengan cara sebelumnya mencoba terlebih dahulu untuk mendetksi jalannya mesin dan hasil setikannya; 4) Meminyaki mesin dengan cara menetesi minyak mesin pada lubang-lubang kecil, sekrup-sekrup dan pada bagian sambungan mesin yang ada pada bagian dalam atau bawah agar jalannya mesin lancar meminyaki mesin sebaiknya dilakukan setiap sesudah mesin jahit digunakan; 5) Setelah mesin diminyaki, dibiarkan beberapa saat, kemudian lap-lap sisa-sisa minyak yang ada pada bagian mesin dengan kain halus; 6) Tutup mesin yang telah dibersihkan jika tidak dipergunakan.

\section{Gangguan dan Perbaikan Mesin Jahit}

Mengatasi gangguan pada mesin jahit, berbagai macam jenis gangguan yang dijumpai pada pemakaian mesin jahit harus dicari penyebabnya dan diusahakan perbaikan-perbaikan agar hasilnya memuaskan. Berikut beberapa petunjuk untuk mengatasi gangguan mesin jahit. :

1. Mesin tidak lancar dan berisik

Perbaikan pada gangguan tersebut dimulai dari membersihkan mesin dari serat-serat kain dan benang yang tertinggal dengan kuas atau sikat. Memberikan minyak pelumas pada throat plate ( penutup gigi) dengan pelumas yang berkualitas baik.

2. Benang jahitan atas sering putus

Perbaikan pada gangguan tersebut dapat dilakukan dengan cara :

a) Mengganti jarum dengan jenis yang baik

b) Menyesuaikan nomor benang dengan nomor jarum yang akan digunakan

c) Setel kembali rumah sekoci dan kendurkan tegangan dengan memperhatikan keseimbangan dengan benang jahit bawah

d) Tarik kain kearah belakang mesin jahit.

3. Benang jahitan bawah sering putus

Perbaikan pada gangguan tersebut dapat dilakukan dengan cara :

a) Bersihkan bagian mekanisme mesin 
b) Garis tengah sekoci harus rata secara keseluruhan sehingga benang lewat pada arah yang seharusnya

c) Kurangi ketegangan dan benang dan sesuaikan dengan tegangan benang atas.

4. Benang sering putus

Perbaikan dapat dilakukan dengan cara :

a) Ganti jarum, sesuaikan antara benang jahit, jarum dan kain

b) Pasanglah jarum pada tempat yang tepat

c) Kendurkan tegangan dengan memperhatikan keseimbangan antara benang atas dan benang bawah jahitan

5. Jarum sering patah

Perbaikan dapat dilakukan dengan cara :

a) Sesuaikan kedudukan jarum pada posisi yang benar

b) Jangan menaruk atau menahan bahan terlalu keras saat proses penjahitan.

6. Jerat benang mengerut

Perbaikan dapat dilakukan dengan cara :

a) Kendurkan tegangan dengan memperhatikan keseimbangan dengan benang jahitan bawah

b) Sesuaikan jarum sehingga benang atas melewati jalan yang benar

c) Sesuaikan nomor jarum dengan bahan yang digunakan

7. Jerat benang kendur

Perbaikan dapat dilakukan dengan cara :

a) Kendurkan tegangan dengan memperhatikan keseimbangan dengan benang jahitan bawah

b) Sesuaikan tegangan benang atas dengan benang bawah

c) Sesuaikan antara benang jahit, jarum dan kain yang akan digunakan.

8. Jalannya kain tidak lancar

Perbaikan dapat dilakukan dengan cara :

a) Bersihkan bagian gigi penyuap kemudian beri pelumas kemudian tutup kembali dengan cepat,

b) Atur mekanisme dengan knop gigi penyuap. 


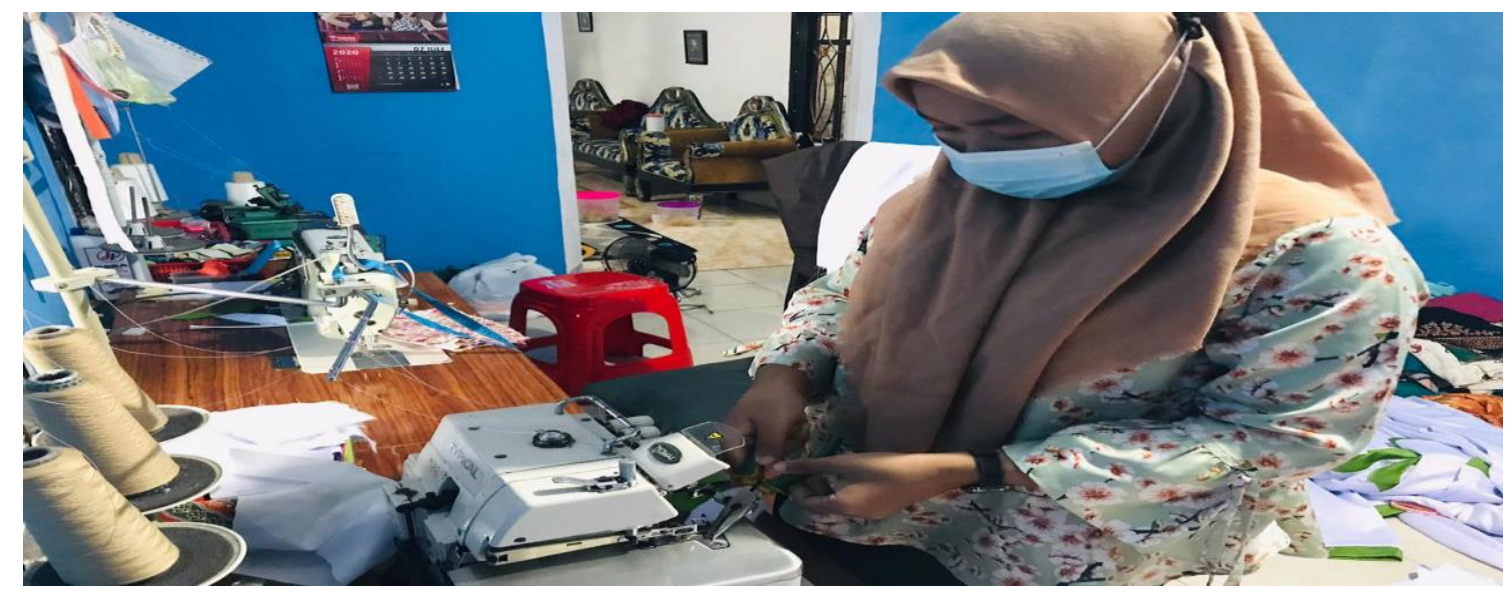

Gambar 4. Peserta sedang melakukan pengencekan pada baut-baut.

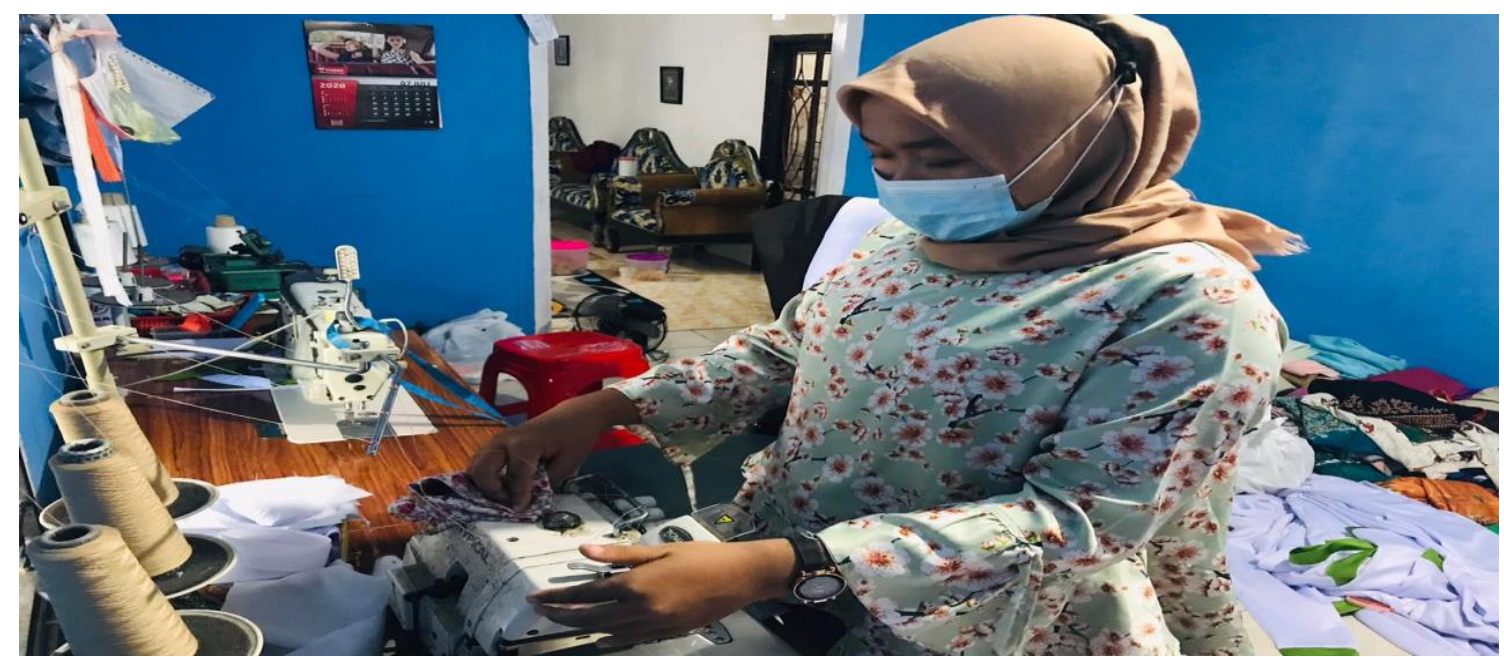

Gambar 5. Peserta sedang membersihkan mesin jahit dengan lap katun.

\section{SIMPULAN}

Pelatihan merupakan proses pembelajaran yang dilaksanakan untuk mencapai suatu kompetensi tertentu dimana materi, metode dan fasilitas pelatihan serta lingkungan belajar yang ada terfokus kepada pencapaian unjuk kerja pada kompetensi yang dipelajari. Pemeliharaan alat jahit ini bertujuan untuk mengetahui bagaimana cara menjaga dan memelihara alat mesin jahit yang benar. Ini dilakukan untuk menambah wawasan kita terhadap hal-hal seperti ini supaya alat jahit terpelihara dengan baik. Serta memperoleh data tentang tata cara memelihara alat jahit.

Pelatihan memelihara alat jahit ini mendapatkan respon yang luar biasa dari peserta pelatihan bahkan mereka meminta agar pemateri bisa melakukan pelatihannya secara berkesinambungan di 
Kelurahan Malasom di masing-masing RT yang ada dalam lingkup Kelurahan Malasom Kabupaten Sorong.

Manfaat dari memelihara alat jahit dengan benar perlu didukung oleh pengetahuan ilmiah yang relevan sehinga meningkatkan serta memperkuat kesadaran masyarakatakan pentingnya merawat mesin dan alat jahit agar dapat bertahan lama dan awet untuk digunakan dalam waktu yang lama. Bentuk kegiatan yang mendukung yakni melalui transfer pengentahuan ilmiah dan implementasinya. Bentuk transfer penetahuan ilmiah tersebut dalam bentuk peyuluhan kepada masyarakat tentang tujuan dan manfaat memelihara alat jahit dalam meningkatkan kualitas dilingkungan masyarakat. Dengan adanya hal tersebut diharapkan masyarakat dapat mengembangkan pengetahuan, keterampilan dan sikap agar siap untuk kerja pada tailor/tempat jahit.

\section{DAFTAR PUSTAKA}

http://www.mb.ipb.ac.id. (n.d.).

Kusnadi, I. H. (2020). Efektifitas Program Pelatihan Berbasis Kompetensi Pada Unit Pelaksana Teknis Daerah Balai Latihan Kerja di Kabupaten Subang. The World of Public Administration Journal, 1(2), 103-124. https://doi.org/10.37950/wpaj.v1i2.739

Latifa, T., \& Maeliah, M. (2016). Tailor sebagai Kesiapan Magang. Jurnal Fesyen Perspektif, $6(1), 82-89$.

Mentari, Dini, and D. L. (2017). ANALISIS PELAKSANAAN KEGIATAN PEMELIHARAAN (MAINTENANCE) TERHADAP KUALITAS PRODUK PADA CV GREEN PERKASA PEMATANGSIANTAR." Maker: Jurnal Manajemen 3.1. Maker: Jurnal Manajemen, 2(2), 26-32. https://maker.ac.id/index.php/maker/article/view/44/44

Ni Wayan Marti. (2017). Seminar Internasional , ISSN 1907-2066 Seminar Internasional , ISSN 1907-2066. Paper Seminar Sistem Informasi Manajemen, 232, 1307-1312.

Pasuruan, I. D. I. (n.d.). Digital Digital Repository Repository Universitas Universitas Jember Jember Digital Digital Repository Repository Universitas Universitas Jember Jember.

Wahyuningtyas, E. (2013). Pengelolaan Program Pelatihan Menjahit Tinngkat Dasar Pada Anak Putus Sekolah Di Balai Latihan Kerja (Blk) Demak. Journal of Nonformal Education and Community Empowerment, 1(2). https://lib.unnes.ac.id/17153/ 